\title{
Erratum to: Comparative effectiveness of urate lowering with febuxostat versus allopurinol in gout: analyses from large U.S. managed care cohort
}

\author{
Jasvinder A. Singh ${ }^{1,2,3,4,6^{*}}$, Kasem S. Akhras ${ }^{5}$ and Aki Shiozawa ${ }^{5}$
}

Unfortunately, the original version of this article [1] contained an error. The Fig. 1 was included incorrectly. The correct Fig. 1 can be found below.

\begin{abstract}
Author details
${ }^{1}$ Medicine Service and Center for Surgical Medical Acute care Research and Transitions (C-SMART), Birmingham VA Medical Center, 700 South 19th Street, Birmingham 35233, AL, USA. ${ }^{2}$ Department of Medicine at School of Medicine, University of Alabama, 1670 University Boulevard, Birmingham 35233, AL, USA. ${ }^{3}$ Division of Epidemiology at School of Public Health, University of Alabama, 1665 University Boulevard, Birmingham 35233, AL, USA. ${ }^{4}$ Department of Orthopedic Surgery, Mayo Clinic College of Medicine, 200 1st St SW, Rochester 55905, MN, USA. ${ }^{5}$ Takeda Pharmaceuticals International, Inc., One Takeda Parkway, Deerfield 60015, IL, USA. ${ }^{6}$ University of Alabama, Faculty Office Tower 805B, 510 20th Street S, Birmingham 35294 AL, USA.
\end{abstract}

Received: 10 August 2015 Accepted: 10 August 2015 Published online: 02 September 2015

\section{Reference}

1. Singh JA, Akhras KS, Shiozawa A. Comparative effectiveness of urate

lowering with febuxostat versus allopurinol in gout: analyses from large U.S. managed care cohort. Arthritis Res Ther. 2015:17:120.

\footnotetext{
* Correspondence: jassingh@uab.edu

${ }^{1}$ Medicine Service and Center for Surgical Medical Acute care Research and Transitions (C-SMART), Birmingham VA Medical Center, 700 South 19th Street, Birmingham 35233, AL, USA

2Department of Medicine at School of Medicine, University of Alabama, 1670 University Boulevard, Birmingham 35233, AL, USA
}

\section{Submit your next manuscript to BioMed Centra and take full advantage of:}

- Convenient online submission

- Thorough peer review

- No space constraints or color figure charges

- Immediate publication on acceptance

- Inclusion in PubMed, CAS, Scopus and Google Scholar

- Research which is freely available for redistribution reproduction in any medium, provided you give appropriate credit to the original author(s) and the source, provide a ink to the Creative Commons license, and indicate if changes were made. The Creative Commons Public Domain Dedication waiver (http://creativecommons.org/publicdomain/zero/1.0/) applies to the data made available in this article, unless otherwise stated. 


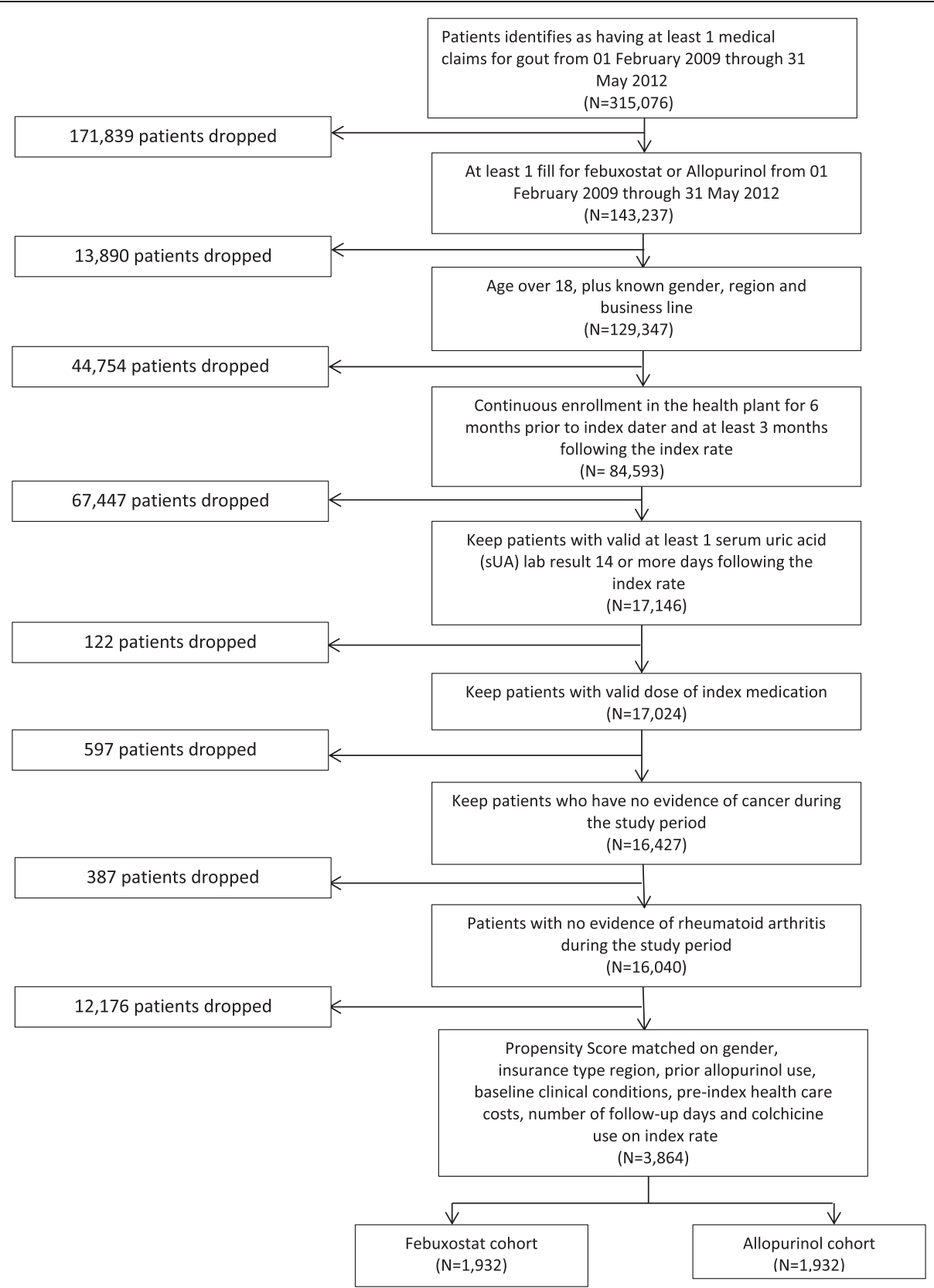

Fig. 1 